\title{
Genetic Variation in Wood Property and Growth of Taiwania (Taiwania cryptomerioides Hayata)
}

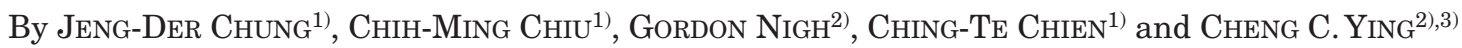

(Received $22^{\text {th }}$ October 2012)

\begin{abstract}
The genetic variation in wood property and growth of Taiwania (Taiwania cryptomerioides) was investigated at two test sites in the same general location, but one at $1200 \mathrm{~m}$ (LK20) and another at $1900 \mathrm{~m}$ (LK24). A rangewide sample of 48 open-pollinated families in Taiwan was involved. The test plantations were 16 years old when the wood property data were collected. Traits studied include wood specific gravity, tracheid length, ring width. $\mathrm{DBH}$ at ages13, 16, and 22 and height at age 13 were also analyzed. Site environment had a dominant effect on growth and wood density, but showed little interaction with family. The site effect was evident in large between-site differences in means, range of family means, and size of family variance components and heritability estimates. These differences are attributable to the site characteristics of LK24 (high elevation, upper slope near a mountain crest) and an unfavourable local climate. Taiwania is fast growing and produces quality wood, and is also an interesting species from the perspective of evolutionary biology. Protection of its genetic variability should be a priority to be managed. We propose that the existing five progeny tests be protected since these tests well-represent the genetic variability of the species in Taiwan.
\end{abstract}

Key words: Taiwania cryptomerioides, genetic variation, site effect, Taiwan.

\section{Introduction}

Taiwan is a sub-tropical island $\left(21^{\circ} 45^{\prime} \mathrm{N}\right.$ to $\left.25^{\circ} 38^{\prime} \mathrm{N}\right)$. Over $35 \%$ of the land is above $1000 \mathrm{~m}$ and over 50 mountains are above $3,000 \mathrm{~m}$. These high mountains add a vertical dimension of biogeoclimatic complexity to the island and results in a temperate zone of forest vegetation with a dominant component of coniferous species, e.g. Chamaecyparis taiwanensis and C. formosensis (LIN et al., 1968). The climate in Taiwan is warm and wet, but is complex and subject to the strong modification of local terrain - hundreds of millimeters of localized stormy rain can occur in a few hours.

Forest vegetation dominates the landscape of Taiwan. About $60 \%$ of the island $\left(36,000 \mathrm{~km}^{2}\right)$ is forested, which harbours a rich forest flora of over 4,000 woody species (LIN et al., 1968; Hsu et al., 2004), many of which pro-

1) Taiwan Forestry Research Institute, 53 Nan-Hai Road, Taipei, Taiwan 10066.

$\left.{ }^{2}\right)$ B.C. Ministry of Forests, Lands and Natural Resource Operations, Forest Analysis and Inventory Branch, P.O. Box 9512, Stn. Prov. Govt., Victoria, B.C., Canada V8W 9C2.

$\left.{ }^{3}\right)$ Corresponding author and visiting scientist at the Taiwan Forestry Research Institute. Retired from the B.C. Ministry of Forests and Range, Research Branch.

E-Mail: cheng.y@telus.net duce high quality wood including Taiwania (Taiwania cryptomerioides). Taiwania is one of the most valuable timber species in Taiwan (KUO, 1995). Trees 50 meters tall and one meter in diameter are common in natural forests (Table 1). With a dominant central stem, the species is known for its high timber recovery rate for saw logs. Its fine-grained wood is easy to process and is suitable for high value products such as wall panelling, veneer, furniture, etc. The species is also very productive; it can sustain over $1 \mathrm{~cm}$ diameter growth past age 40 and produces over $600 \mathrm{~m}^{3} \mathrm{ha}^{-1}$ at age 40 (KuO, 1995). Silviculture treatments such as space control can give rise to more volume and a higher percentage of largediameter trees (CHIU et al., 2010a, 2010b). It has been a major species for planting with over 6,100 ha of plantations in existence in 2000 (WORLD FOREST InstituTe, 2001).

Taiwania is a fascinating species from a botanical perspective. LIU and SU (1983) probably did the most comprehensive systematic research of this species. The following synopsis of its ecological and botanical characteristics is largely based on their report. It is a relic species, often referred to as a 'living fossil' along with species like Metasequoia, Gingko, and Sequoia, whose existence can be traced back to the Tertiary Period. Taiwania was first found in central Taiwan by Konishi in 1904 and it is a monotypic genus, first thought to be endemic to Taiwan. Residual extant populations have later been found throughout southwest China and neighbouring Burma (LI et al., 2008). Fossil evidence further suggests the species once had a much wider geographic distribution. The species can be found in natural forests throughout the Central Mountain Range in Taiwan $\left(22^{\circ} 30^{\prime} \mathrm{N}\right.$ to $24^{\circ} 30^{\prime} \mathrm{N}$ ) (Figure 1) from 1600 to 2600 $\mathrm{m}$ elevation. Seedlings require exposed soil to become established and are not shade tolerant. Edaphic factors rather than climate restrict its local distribution.

Taiwania is characteristically large in size, comparable to Sequoia in North America. In natural forests, trees over $60 \mathrm{~m}$ tall and $3 \mathrm{~m}$ in diameter are not uncommon. The species has a long life span (> 100 years), late reproductive maturity (cone production starts at about age 45 , but can continue to well over 100 years in natural forests), small seeds (1500 per gram), and infrequent cone crops (LIU and Su, 1983; KUO, 1995). Even in managed seed orchards, it could take 40 years to produce only a small quantity of seeds (CHUNG et al., 2001). This suggests that the species lacks ecological amplitude in inter-specific competition, and its perpetuation largely is due to its longevity and size (LIU, 1966; LIU and SU, 1983). The International Union of Conservation Network includes Taiwania in its 'Global Red List of 
Table 1. - Summary statistics for the provenance and parent tree information (see Figure 1 for provenance locations). Means and ranges (in parentheses) are reported.

\begin{tabular}{|c|c|c|c|c|c|c|c|c|}
\hline \multicolumn{2}{|r|}{ Provenance } & \multirow{2}{*}{$\begin{array}{l}\text { Number of } \\
\text { families }^{\mathrm{a}}\end{array}$} & \multirow{2}{*}{$\begin{array}{c}\text { Height } \\
\text { (m) }\end{array}$} & \multirow{2}{*}{$\begin{array}{l}\text { Crown } \\
\text { height (m) }\end{array}$} & \multirow[b]{2}{*}{$\mathrm{DBH}(\mathrm{cm})$} & \multirow{2}{*}{$\begin{array}{l}\text { Bark thick- } \\
\text { ness (cm) }\end{array}$} & \multirow{2}{*}{$\begin{array}{c}\text { Elevation } \\
\text { (m) }\end{array}$} & \multirow[b]{2}{*}{ Slope (?) } \\
\hline Code & Location & & & & & & & \\
\hline 1 & Tahsuehshan & $\begin{array}{c}42 \\
(8,15)\end{array}$ & $\begin{array}{c}47.9 \\
(30-75)\end{array}$ & $\begin{array}{c}25.1 \\
(15-50)\end{array}$ & $\begin{array}{c}230 \\
(92-350)\end{array}$ & $\begin{array}{c}1.33 \\
(0.6-2.3)\end{array}$ & $\begin{array}{c}2129 \\
(1600-2500)\end{array}$ & $\begin{array}{c}20.7 \\
(8-40)\end{array}$ \\
\hline 2 & Guanshan & $\begin{array}{c}29 \\
(9,8)\end{array}$ & $\begin{array}{c}41.8 \\
(30-56)\end{array}$ & $\begin{array}{c}21.9 \\
(12-36)\end{array}$ & $\begin{array}{c}173 \\
(100-296)\end{array}$ & $\begin{array}{c}1.8 \\
(0.9-4.2)\end{array}$ & $\begin{array}{c}2179 \\
(1980-2340)\end{array}$ & $\begin{array}{c}31.6 \\
(17-45)\end{array}$ \\
\hline 3 & Wangxiang & $\begin{array}{c}20 \\
(5,12)\end{array}$ & $\begin{array}{c}58.7 \\
(30-90)\end{array}$ & $\begin{array}{c}32.8 \\
(11-65)\end{array}$ & $\begin{array}{c}194 \\
(146-264)\end{array}$ & $\begin{array}{c}1.4 \\
(0.6-2.1)\end{array}$ & $\begin{array}{c}2088 \\
(1750-2280)\end{array}$ & $\begin{array}{l}25.5 \\
(5-40)\end{array}$ \\
\hline 4 & Dajian & $\begin{array}{c}19 \\
(2,7)\end{array}$ & $\begin{array}{c}44.9 \\
(39-60)\end{array}$ & $\begin{array}{l}23.4 \\
(8-39)\end{array}$ & $\begin{array}{c}227 \\
(140-380)\end{array}$ & $\begin{array}{c}1.5 \\
(0.8-2.8)\end{array}$ & $\begin{array}{c}2044 \\
(1750-2280)\end{array}$ & $\begin{array}{c}45.6 \\
(15-75)\end{array}$ \\
\hline 5 & Xiuluan & $\begin{array}{c}7 \\
(3,1)\end{array}$ & $\begin{array}{c}47.2 \\
(42-52)\end{array}$ & $\begin{array}{c}31.8 \\
(24-38)\end{array}$ & $\begin{array}{c}108 \\
(69-185)\end{array}$ & $\begin{array}{c}1.6 \\
(1.2-2.5)\end{array}$ & $\begin{array}{c}2098 \\
(1920-2240)\end{array}$ & $\begin{array}{c}21.2 \\
(15-30)\end{array}$ \\
\hline 6 & Danta & $\begin{array}{c}6 \\
(1,5)\end{array}$ & $\begin{array}{c}80.7 \\
(75-90)\end{array}$ & $\begin{array}{c}40.2 \\
(35-45)\end{array}$ & $\begin{array}{c}169 \\
(90-258)\end{array}$ & $\begin{array}{c}1.5 \\
(0.8-2.4)\end{array}$ & $\begin{array}{c}2284 \\
(1950-2540)\end{array}$ & $\begin{array}{c}23.2 \\
(20-30)\end{array}$ \\
\hline 7 & Liwuxi & $\begin{array}{c}3 \\
(1,0)\end{array}$ & $\begin{array}{c}31 \\
(29-34)\end{array}$ & $\mathrm{N} / \mathrm{A}$ & $\begin{array}{c}116.0 \\
(96-132)\end{array}$ & $\mathrm{N} / \mathrm{A}$ & $\mathrm{N} / \mathrm{A}$ & N/A \\
\hline Mean & total) & $\begin{array}{c}131 \\
(30,48)\end{array}$ & 48.3 & 26.1 & 200.9 & 1.5 & 2126 & 27.7 \\
\hline
\end{tabular}

a The numbers inside the parentheses are the number of families included in the wood property study at site LK20 (the first number) and at site LK24 (the second number).

Conifers' as a priority species for conservation (FARJON and PAGE, 1999).

For genetic selection and breeding, long-term field tests were established at five sites in the late 1970s and early 1980s. Operational tree improvement of Taiwania never materialized mainly due to a seed production problem in the seed orchard, and also due to rapid changes in the social, economic and industrial structures so that the recreational and environmental values of forests in Taiwan are greater than its timber value. However, all the field test sites have been well maintained and periodically measured. Wood density and its component elements (tracheid length [TL] and ring width [RW]) were assessed at two sites (Figure 1). In this report, we focus on the genetic variation of specific gravity (SG), its associated component elements, and growth from these two test sites.

\section{Materials and Methods}

Data

The Taiwan Forestry Research Institute initiated a substantial genetic program of the species in early
Table 2. - Properties of the test sites Liouguei20 (LK20) and Liouguei24 (LK24).

\begin{tabular}{|l|c|c|}
\hline & \multicolumn{2}{|c|}{ Site $^{\text {a }}$} \\
\hline Properties & LK20 & LK24 \\
\hline Elevation (m) & 1200 & 1900 \\
\hline Provenances & 7 & 7 \\
\hline Families & 30 & 70 \\
\hline Blocks & 10 & 10 \\
\hline Plot size (ha) & 4 & 4 \\
\hline Spacing (m) & $2 \times 2$ & $2 \times 2$ \\
\hline Survival (\%) & 54 & 73 \\
\hline Year of planting & 1985 & 1986 \\
\hline
\end{tabular}

a Data on wood property were collected in 2002 when the LK20 test was 17 years old and the LK24 was 16 years old.

${ }^{\text {b }}$ Survival at age 22 . 


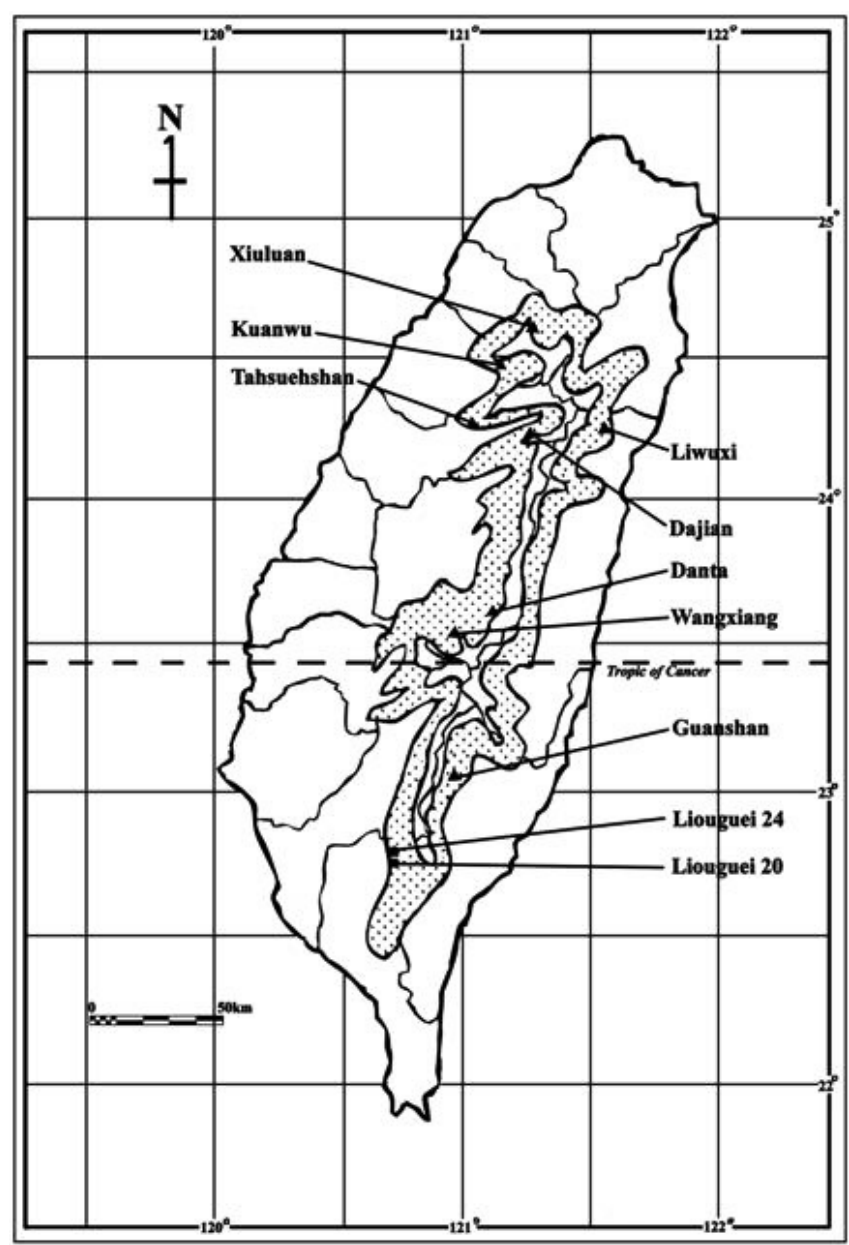

Figure 1. - Geographic locations of the parent trees $(\mathbf{\Delta})$ and test sites (๑).

1970s and completed seed collections from 1974 to 1979 from a total of 131 trees from throughout the species distribution range in Taiwan (Table 1, Figure 1). In such extremely mountainous terrain, seed collection by climbing trees over $30 \mathrm{~m}$ tall, some $90 \mathrm{~m}$ tall, was not a small task. The early results from nursery and short-term studies suggest some provenance differences in germination characteristics (LU, 1973), and in seedling characteristics in branching and stem elongation (LU, 1975), but variation in seedling growth was mostly among families within provenance (LIU et al., 1985)

Five long-term Taiwania provenance tests with openpollinated families were established from 1979 to 1986 , two in central and three in southern Taiwan, using $2+1$ bare-root seedlings. The three southern test sites are representative of the typical forest lands where Taiwania is commonly planted. The wood property study reported here was done at two southern tests, Liouguei 20 (LK20) and Liouguei 24 (LK24) (Figure 1). Test LK20 was planted in 1985 and LK24 was planted in 1986. The two test sites are in the same locality, but are separated by $700 \mathrm{~m}$ in elevation (Table 2). A randomized complete block design with 10 replications of 4 -seedling line plots at $2 \times 2 \mathrm{~m}$ spacing (Table 2 ) were established at both tests with family as the treatment (the provenance identities were maintained in the data). All 30 families from 7 provenances at LK20 and 48 out of the 70 families at LK24 (from 6 provenances) were included in the wood property study (Table 2). Twenty families were common to both sites. Sample increment cores were collected in 2002 when the trees were 16 and 17 years of age (plantation ages), respectively, at LK24 and LK20 (Table 2). At LK24, increment cores were taken from 4, or occasionally 3 , trees in each family and one tree only from each block. At the LK20 site, the sampling procedure was the same as at LK24 except the number of sample trees for increment cores varied from 4 to 10 . The trees sampled for the study were usually the most vigorous ones in each plot with at least 3 healthy living trees. Using the most vigorous trees instead of random trees for a wood property study is the common practice in Taiwan (e.g. YANG et al., 2001a; YANG et al., 2001b; YANG and CHIU, 2006). YANG et al. (2001a) reasoned that the vigorous trees are likely to be representative of future selections for breeding or silviculture use, and are less
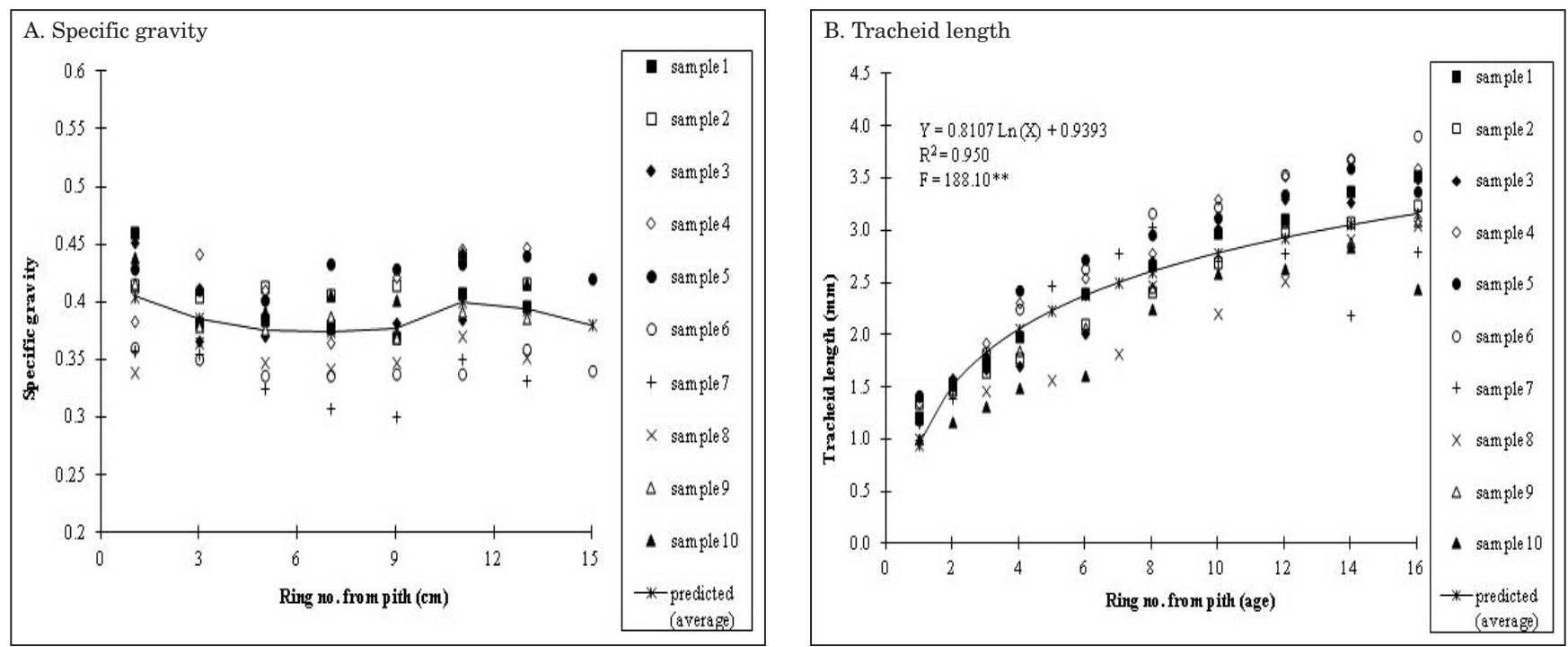

Figure 2. - Age trends in wood specific gravity and tracheid length. 
Table 3. - Expected mean squares for the variance components for the test sites considered individually and combined, assuming all the effects are random.

\begin{tabular}{|c|c|c|c|}
\hline & \multicolumn{3}{|c|}{ Expected mean squares } \\
\hline Source & $\mathrm{LK} 20^{\mathrm{at}}$ & $\mathrm{LK} 24^{\mathrm{b}}$ & Both sites \\
\hline Family & $\sigma^{2}+k_{1} \sigma^{2}$ & $\sigma^{2}+k_{l} \sigma^{2}$ & $\sigma^{2}+k_{l} \sigma_{j 5}^{2}+k_{2} \sigma_{p}^{2}$ \\
\hline Site & $\mathrm{N} / \mathrm{A}$ & $\mathrm{N} / \mathrm{A}$ & $\sigma^{2}+k_{3} \sigma_{f_{s}}^{2}+k_{1} \sigma_{s}^{2}$ \\
\hline Site $\times$ Camily & $\mathrm{N} / \mathrm{A}$ & $\mathrm{N} / \mathrm{A}$ & $\sigma^{2}+k_{5} \sigma_{14}^{2}$ \\
\hline Residual & $\sigma^{2}$ & $\sigma^{2}$ & $\sigma^{2}$ \\
\hline
\end{tabular}

${ }^{\mathrm{a}} \mathrm{k}_{1}=5.782$ for DBH16, ETL, TLT, ATL, SG, and RW; $\mathrm{k}_{1}=5.5821$ for DBH13 and HT13; $\mathrm{k}_{1}=5.2774$ for DBH22.

${ }^{\mathrm{b}} \mathrm{k}_{1}=3.8326$ for DBH16, ETL, LTL, ATL, SG, and RW; $\mathrm{k}_{1}=3.7698$ for DBH13 and $\mathrm{HT} 13 ; \mathrm{k}_{1}=1.7058$ for DBH22.

${ }^{\mathrm{c}} \mathrm{k}_{1}=4.5882$ for DBH16, ETL, LTL, ATL, SG, and RW; $\mathrm{k}_{1}=4.4586$ for DBH13 and HT13; $\mathrm{k}_{1}=2.4852$ for DBH22; $\mathrm{k}_{2}=9.1764$ for DBH16, ETL, LTL, ATL, SG, and RW; $\mathrm{k}_{2}=8.9172$ for DBH13 and HT13; $\mathrm{k}_{2}=4.9703$ for DBH22; $\mathrm{k}_{3}=4.4906$ for DBH16, ETL, LTL, ATL, SG, and RW; $\mathrm{k}_{3}=4.3214$ for DBH13 and HT13; $\mathrm{k}_{3}=2.2792$ for DBH22; $\mathrm{k}_{4}=89.812$ for DBH16, ETL, LTL, ATL, SG, and RW; $\mathrm{k}_{4}=86.427$ for DBH13 and HT13; $\mathrm{k}_{4}=45.583$ for DBH22; $\mathrm{k}_{5}=4.5882$ for DBH16, ETL, LTL, ATL, $\mathrm{SG}$, and RW; $\mathrm{k}_{5}=0.4586$ for DBH13 and HT13; $\mathrm{k}_{5}=2.4852$ for DBH22.

likely to cause permanent injury to the sample trees (WUNDER et al., 2011). Diameters of the sample trees at $1.3 \mathrm{~m}$ height $(\mathrm{DBH})$ were also measured.

Increment cores were taken at a height of $1.3 \mathrm{~m}$ from the upper slope side and through the pith (LEE and WAHLGREN, 1979; YANCHUK and KISS, 1993). The outermost 6 rings of each increment core (the experimental unit) were cut under a magnifying glass for the specific gravity (SG), ring width (RW), and tracheid length (TL) analyses (LEE and WAHLGREN, 1979; YANG et al., 1998).

The outermost 6 rings were determined to be satisfactory using the following methodology. The horizontal variation (age trend) in ten randomly selected complete (pith to bark) increment cores were cut into sections of $1.5 \mathrm{~cm}$ in length. SG was determined for each section following the procedure below. For horizontal profiling of $\mathrm{TL}$, each ring was analyzed individually. The results of the SG and TL analyses are shown in Figure 2. There was no clear age trend in SG (Figure 2a); therefore, the average $\mathrm{SG}$ of the outermost six rings is an adequate measure to represent individual trees. The TL analysis showed an age trend on a logarithmic scale (Figure 2b), which increased before age 6 and after that the increase started to level off (Figure 2b). The outermost 6 rings is also a good representative measure of TL.

We used the maximum moisture content method (SMITH, 1954) to determine SG. The procedure is as follows:

1. Remove the extractives: Each sample core was labelled and soaked in a mixture of benzene : ethanol solution in a $2: 1$ ratio by volume for a week to soften and dissolve the extractives for easy removal;

2. Saturate the increment core sample with water: The benzene : ethanol solution in the container was removed with a vacuum pump. The sample core was then thoroughly soaked in water till a constant saturated sample core weight was reached;

3. Determine the absolute dry weight: Each core sample was dried in an oven at $105 \pm 2{ }^{\circ} \mathrm{C}$ for about 72 hours, and weighed for its absolute weight to the nearest 0.001g;

4. Calculate the SG: SG was calculated according to the following equation:

$$
\mathrm{SG}=1 /[(\mathrm{Mm}-\mathrm{Mo}) / \mathrm{Mo}+(1 / 1.53)],
$$

where $\mathrm{Mm}$ is the water saturated weight of the wood core sample, Mo its absolute dry weight, and 1.53 is the average specific gravity of wood substance (SMITH, 1954).

The TL was determined from the same 6-ring increment core sample after the SG was measured. The core was cut under a magnifying glass into individual rings and placed in a test tube filled with a solution of one part $\mathrm{H}_{2} \mathrm{O}_{2}, 5$ parts glacial acetic acid, and 4 parts distilled water, and placed in a $40^{\circ} \mathrm{C}$ oven for chemical maceration for about a week (FRANKLIN, 1945). After maceration, the fibrous tracheids were washed with distilled water, dispersed, mounted on microscope slides, and stained with Safranin-O. To determine a proper sample size, 100 tracheids were randomly sampled and their length was measured under a profile projector. Based on the standard deviation of TL, a sample size of 76 tracheids would be sufficient to achieve a $5 \%$ allowable error (SNEDECOR and COCHRAN, 1980). We used a sample size of 80 tracheids per ring for the measurement of TL for both early (ETL) and late (LTL) wood.

Total height at age 13 (HT13) and diameter at ages 13 (DBH13) and 22 (DBH22) from the two tests were added to the data set. A total of 9 traits were available for this study: SG (specific gravity), ETL (earlywood tracheid 
length), LTL (latewood tracheid length), ATL (average tracheid length $=($ ETL + LTL)/2) $)$ RW (ring width), DBH13 (diameter at age 13), DBH16 (diameter at age 16), DBH22 (diameter at age 22), and HT13 (total height at age 13). Even though the two test sites were planted 10 months apart, we did not consider the age difference in our analyses since the site effect is so overwhelming.

\section{Statistical Analysis}

The relative size of variance components (VC) and means associated with the genetic sources are the focal statistics in our analyses. We used SAS procedure MIXED (SAS INSTITUTE INC., 2004) with the REML method to estimate variance components and to produce best linear unbiased predictions of family means (LIT-
TELL et al., 1996). Procedure MIXED sets negative variance components to 0 , recalibrates the size of the variance components, and produces identical means for the sources that have a 0 variance component. These two features are attractive conceptually and in application.

Variance components and means were estimated based on the following linear models:

$\mathrm{Y}_{\mathrm{jk}}=\mu+\mathrm{F}_{\mathrm{jk}}+\varepsilon_{\mathrm{jk}}$ for single-site analysis, and

$\mathrm{Y}_{\mathrm{ijk}}=\mu+\mathrm{S}_{\mathrm{i}}+\mathrm{F}_{\mathrm{j}}+\mathrm{SF}_{\mathrm{ij}}+\varepsilon_{\mathrm{ijk}}$ for the joint analysis combining the two test sites

where $\mathrm{Y}_{\mathrm{jk}}$ or $\mathrm{Y}_{\mathrm{ijk}}$ is the value of wood and growth traits of tree $\mathrm{k}$ from the $\mathrm{j}^{\text {th }}$ family planted in the $\mathrm{i}^{\text {th }}$ site, $\mu$ is the overall mean, $\mathrm{S}$ is the effect of test site, $\mathrm{F}$ is the family effect, $\mathrm{SF}$ is the site-family interaction, and $\varepsilon$ is the error term. All factors are random.

Table 4. - Variance components, also expressed as intra-class correlation (\% of the total variance in parentheses), of the wood and growth traits from the analyses of variance by individual sites.

\begin{tabular}{|c|c|c|c|c|}
\hline \multirow[t]{2}{*}{ Trait/Source } & \multicolumn{2}{|c|}{ LK20 } & \multicolumn{2}{|c|}{ LK24 } \\
\hline & l'amily & Residual & Family & Residual \\
\hline Degrees of Freedom & 29 & 144 & 47 & 136 \\
\hline \multirow[t]{2}{*}{$\mathrm{SG}$} & $0.000319^{*}:$ & 0.000809 & 0.000019 & 0.001915 \\
\hline & (28) & (72) & (1) & (99) \\
\hline \multirow[t]{2}{*}{ l:TI. } & 0.003397 & 0.07909 & 0.005232 & 0.06477 \\
\hline & (4) & (96) & (7) & (93) \\
\hline \multirow[t]{2}{*}{ LTL } & 0.003000 & 0.09958 & 0.001423 & 0.07128 \\
\hline & (3) & $(97)$ & (2) & (98) \\
\hline \multirow[t]{2}{*}{ ATL } & 0.002597 & 0.08171 & 0.002569 & 0.06475 \\
\hline & (3) & (97) & (4) & (96) \\
\hline \multirow[t]{2}{*}{ RW } & 0.003146 & 0.04971 & 0.000987 & 0.05048 \\
\hline & (6) & (94) & (2) & (98) \\
\hline \multirow[t]{2}{*}{ DBI113 } & $5.5188^{*}$ & 19.5302 & $2.8185^{*}$ & 16.0123 \\
\hline & (22) & (78) & (15) & (85) \\
\hline \multirow[t]{2}{*}{ DBH16 } & $3.5040^{*}$ & 22.2303 & 2.3143 & 26.2936 \\
\hline & (14) & (86) & (8) & (92) \\
\hline \multirow[t]{2}{*}{ DBH22 } & $8.8051^{*}$ & 34.4065 & 1.2232 & 29.2364 \\
\hline & $(20)$ & $(80)$ & (4) & (96) \\
\hline \multirow[t]{2}{*}{ HT13 } & $1.009]^{*}$ & 4.2178 & 0.00 & 1.2652 \\
\hline & (19) & $(81)$ & $(0)$ & 100 \\
\hline
\end{tabular}

* Statistically significant at $p=0.05 ;{ }^{* *}$ significant at $p=0.01$; otherwise not significant (Wald Z statistics, SAS Procedure MIXED). 
We excluded provenance as a factor in the above analyses because of the peculiarities of the biogeoclimatic environments and forest landscape in Taiwan (CHUNG et al., 2011). For example, the complex mountainous topography and climate render the delineation of provenance boundaries difficult. Zonation in forest resource management is uneconomical due to the species' limited distribution range and in which mixed-species stand of numerous component species but with a small number of trees per member species is the norm. More importantly, our initial analysis showed the VCs for provenance and its interaction with site were mostly 0 or approaching 0 . Also, trivial provenance effects appear to be common among coniferous species native to Taiwan in both growth, wood traits, and molecular markers, e.g. Konishii fir (Cunninghamia lanceolata var. konishii)
(LIN et al. 1998; YANG et al., 2001a; CHUNG et al., 2011), Taiwan incense cedar (Calocedrus formosana) (YANG and CHIU, 2006), and China fir (Cunninghamia lanceolata) (YANG, et al., 2001b). We also excluded block as a factor. In progeny testing of tree species, it is rarely explicit on the factor that is associated with blocking. That block is statistically a random or fixed effect is mostly a subjective decision, which can complicate the analysis and statistical interpretation. We consider blocking to be a way to facilitate randomization within the site in a mountainous terrain.

The following analysis for heritability estimates and between-trait genetic correlation is mainly for biological interest. Genetic selection for improvement is not the goal of the analysis in this report. Late reproductive maturity (40 years of age or older) (LIU and SU, 1983)

Table 5. - Variance components, also expressed as intra-class correlation (\% of the total variance in parentheses), of wood and growth traits from the combined of analyses of variance of both sites using the 20 families common to both sites.

\begin{tabular}{|c|c|c|c|c|}
\hline Trait/Source & Site & Family & Site $\times$ Family & Residual \\
\hline Degrees of freedom & 1 & 19 & 19 & $158^{2}$ \\
\hline \multirow[t]{2}{*}{$\mathrm{SG}$} & 0.000046 & $0.000235 *$ & 0.00 & 0.001349 \\
\hline & (3) & (14) & (0) & $(83)$ \\
\hline \multirow[t]{2}{*}{ FTL } & $0.0726 I$ & 0.004100 & 0.00 & 0.7076 \\
\hline & (49) & (3) & (0) & (49) \\
\hline \multirow[t]{2}{*}{$\mathrm{ITI}$} & 0.08675 & 0.005830 & 0.00 & 0.08622 \\
\hline & (49) & (3) & (0) & (48) \\
\hline \multirow[t]{2}{*}{ ATL } & 0.07921 & 0.004866 & 0.00 & 0.07235 \\
\hline & (51) & (3) & (0) & (46) \\
\hline \multirow[t]{2}{*}{ RW } & 0.004265 & 0.003819 & 0.00 & 0.04681 \\
\hline & (8) & (7) & (0) & (85) \\
\hline \multirow[t]{2}{*}{$\mathrm{DBH} 13$} & 31.0544 & $5.1496^{*}$ & 0.3348 & 18.8930 \\
\hline & (56) & (9) & (1) & (34) \\
\hline \multirow[t]{2}{*}{ DBH16 } & 4.7043 & $5.2656^{*}$ & 0.00 & 22.9755 \\
\hline & (14) & (16) & (0) & $(70)$ \\
\hline \multirow[t]{2}{*}{$\mathrm{DBH} 22$} & 5.7503 & $9.9551 *$ & 0.00 & 31.9828 \\
\hline & (12) & (21) & (0) & (67) \\
\hline \multirow[t]{2}{*}{ HT13 } & 14.2466 & $0.7680^{* *}$ & 0.03618 & 3.5601 \\
\hline & (76) & (4) & $(<1)$ & (19) \\
\hline
\end{tabular}

a 150 for HT13 and DBH13, and 103 for DBH22.

* Statistically significant at $\mathrm{p}=0.05$; otherwise not significant (Wald Z statistics, SAS Procedure MIXED). 
poses a serious biological constraint on Taiwania as a candidate species for tree improvement. Also, multiplespecies operational tree improvement is not an economically viable option in Taiwan due largely to the limited land base (CHUNG et al., 2011).

Individual tree heritability $\left(\mathrm{h}_{\mathrm{i}}^{2}\right)$ and family heritability $\left(\mathrm{h}_{\mathrm{f}}^{2}\right)$ were estimated using the following equations (NyQUIST, 1991) (See Table 3 for expected mean squares in variance components estimates and their coefficients):

$$
\begin{aligned}
\mathrm{h}^{2}{ }_{\mathrm{i}}= & 4 \times \sigma_{\mathrm{f}}^{2} /\left(\sigma^{2}+\sigma_{\mathrm{f}}^{2}\right) \text { for individual sites, and } \\
\mathrm{h}^{2}= & 4 \times \sigma_{\mathrm{i}}^{2} /\left(\sigma^{2}+\sigma_{\mathrm{fs}}^{2}+\sigma_{\mathrm{f}}^{2}\right) \text { for the two sites } \\
& \text { combined; } \\
\mathrm{h}^{2}{ }_{\mathrm{f}}= & \sigma_{{ }_{\mathrm{f}}}^{2} /\left(\left(\sigma^{2}+5.5821 \sigma_{\mathrm{f}}^{2}\right) / 5.5821\right) \\
= & \sigma_{\mathrm{f}}^{2} /\left(\sigma^{2} / 5.7820+\sigma_{\mathrm{f}}^{2}\right) \text { for site LK20 and } \\
\mathrm{h}^{2}= & \sigma_{\mathrm{f}}^{2} /\left(\sigma^{2} / 3.8326+\sigma_{\mathrm{f}}^{2}\right) \text { for site LK24 } \\
\mathrm{h}_{\mathrm{f}}^{2}= & \sigma_{\mathrm{f}}^{2} /\left(\sigma^{2}+4.5882 \sigma_{\mathrm{fs}}^{2}+9.1764 \sigma_{\mathrm{f}}^{2}\right) / 9.1764 \\
= & \sigma_{\mathrm{f}}^{2} /\left(\sigma^{2} / 9.1764+0.5 \sigma_{\mathrm{fs}}^{2}+\sigma_{\mathrm{f}}^{2}\right) \text { for the two sites } \\
& \text { combined. }
\end{aligned}
$$

The VC coefficients for heritability estimates vary somewhat for different traits and can be found in Table 3. We calculated genetic correlations between traits using the following equation:

$$
R_{x y}=\operatorname{cov}(x y) /\left(\sigma_{x} \sigma_{y}\right) \text {, }
$$

Where $\operatorname{cov}(\mathrm{xy})$ is the covariance between trait $\mathrm{x}$ and $\mathrm{y}$ and $\sigma_{\mathrm{x}}$ and $\sigma_{\mathrm{y}}$ are the square root of their family VC.

\section{Results}

The most interesting result of this study is that environment (site) showed a huge impact on both wood and growth traits, but there is little site-family (genetic) interaction (Tables 4 and 5). Site accounted for 3 to $76 \%$ of the total variance (averaged 35\% across traits), whereas $\mathrm{VCs}$ for the site-family interaction were 0 for most of the traits with the largest VC accounting for only $1 \%$ of the total variance (Table 5). At site LK20 the family VCs accounted for 3 to $28 \%$ of the total variance (13\% average across traits), and at site LK24 the family VCs accounted for 0 to $15 \%$ (5\% average) (Table 4). The family VC for HT13 and SG were 19 and $28 \%$ for the LK20 site, respectively, and were 0 and $1 \%$ for the LK24 site, respectively. This shows the suppressing effect of site LK24 on variation. Differences in family VCs for $\mathrm{DBH}$ between the sites were also large, though not as large as for SG and HT13. Family VCs for the wood component traits TL and RW changed little between sites and their error VCs accounted for nearly $100 \%$ of the total variance at both sites (Table 4). This suggests these wood component traits are sensitive to micro-site environments and are under low genetic control.

The site means of all traits except RW were higher at LK20 than at LK24 and the coefficients of variation (CVs) were much smaller at LK24 for most traits (Table

\begin{tabular}{|c|c|c|}
\hline \multirow[b]{2}{*}{ Trait } & I_K20 & L.K24 \\
\hline & Means & Means \\
\hline \multirow[t]{2}{*}{$\mathrm{SG}$} & 0.351 & 0.340 \\
\hline & $(5.1)$ & $(0.4)$ \\
\hline \multirow[t]{2}{*}{ ETI } & 3.183 & 2.823 \\
\hline & $(1.8)$ & (2.6) \\
\hline \multirow[t]{2}{*}{ LTL } & 3.311 & 2.911 \\
\hline & $(1.7)$ & $(1.3)$ \\
\hline \multirow[t]{2}{*}{ ATL } & 3.247 & 2.868 \\
\hline & (1.6) & $(1.8)$ \\
\hline \multirow[t]{2}{*}{ RW } & 0.632 & 0.755 \\
\hline & $(8.9)$ & $(4.2)$ \\
\hline \multirow[t]{2}{*}{ DBH13 } & 24.43 & 16.36 \\
\hline & $(9.6)$ & $(10.3)$ \\
\hline \multirow[t]{2}{*}{ DBI116 } & 28.11 & 24.90 \\
\hline & $(6.7)$ & (6.1) \\
\hline \multirow[t]{2}{*}{$\overline{\mathrm{DBH}} 22$} & 32.95 & 28.86 \\
\hline & $(9.0)$ & $(3.8)$ \\
\hline \multirow[t]{2}{*}{ HT13 } & 12.49 & 6.78 \\
\hline & $(8.0)$ & $(0.0)$ \\
\hline
\end{tabular}
6). Average HT13 at LK20 was almost twice as much as average HT13 at LK24. The CV at site LK24 was $0 \%$. The site effect on diameter was much less pronounced than on height. The age trend of the CVs for $\mathrm{DBH}$ showed a rapid decline at site LK24, going from $10.3 \%$ at age 13 (DBH13) to $3.8 \%$ at age 22 (DBH22), whereas at LK20 the CVs varied from 6.7 to $9.0 \%$ and showed no
Table 6. - Site means and coefficients of variation (= family $\sigma_{\mathrm{f}} /$ site mean $\times 100 \%$, in parentheses) of wood and growth traits.

age trend. Site LK24 had similar suppressing effect on SG, with a mean of 0.340 and CV $0.4 \%$ compared to a mean of 0.351 and CV $5.1 \%$ at LK20 (Table 6). The unfavourable environment at LK24 (see Discussion) reduced the site means and also shrank the range of family means (low CV). If the site effect operates on means alone, then the CVs should be similar between the two sites (SNEDECOR and COCHRAN, 1980).

Estimates of heritability (Table 7 ) reflect basically the same pattern of variation as in the VC analyses, that is, there is a strong site effect. Both individual-tree $\left(\mathrm{h}^{2}{ }_{\mathrm{i}}\right)$ and family heritability $\left(\mathrm{h}_{\mathrm{f}}^{2}\right)$ were substantially larger at site LK20 than at LK24; average $h^{2}$ and $h^{2}$ were 0.53 and 0.41 at LK20 and 0.19 and 0.14 at LK24, respectively. Heritability estimates for HT13 dropped to 0 at LK24 for both $\mathrm{h}^{2}{ }_{\mathrm{i}}$ and $\mathrm{h}_{\mathrm{f}}{ }_{\mathrm{f}}$, and similarly for $\mathrm{SG}$ and $\mathrm{DBH}$ but to a lesser degree (Table 7). However, at LK20, the heritability estimates for both DBH and SG were comparable to those of other coniferous tree species (ZOBEL and VAN BuiJtenen, 1989; Wu et al., 2008; GASPAR et al., 2008; CHung et al., 2011). 
A large site effect without a site-family interaction (Table 5) is an interesting phenomenon that required further exploration. We repeated the variance analysis with the same model but with the site effect removed by subtracting site means from the data. The results were identical to that in Table 5: no family-site interaction. This indicates that the large site difference, which could overwhelm (mask) the interaction, is not the cause of this phenomenon. The family-site interaction consists of two main causal components: the ranking of family means and the family variance (SHELBOURNE and CAMPBELL, 1976; MATHESON and CotTERILL, 1990). Except for HT13, which had a correlation of 0 because the variance for HT13 at LK24 was 0, the correlation of family means

Table 7. - Estimates of individual $\left(\mathrm{h}_{\mathrm{i}}^{2}\right)$ and family $\left(\mathrm{h}_{\mathrm{f}}^{2}\right)$ heritability.

\begin{tabular}{|c|c|c|c|c|c|c|}
\hline \multirow[b]{2}{*}{ Trait } & \multicolumn{2}{|c|}{ I. $\mathrm{K} 20$} & \multicolumn{2}{|c|}{ l.K24 } & \multicolumn{2}{|c|}{ I.K20 and I.K24 } \\
\hline & $\mathrm{b}_{\mathrm{i}}^{2}$ & $\overline{\mathrm{h}_{\mathrm{f}}^{2}}$ & $\mathrm{~h}^{2}{ }_{\mathrm{i}}$ & $\mathbf{h}_{\mathrm{f}}^{2}$ & $\mathrm{~h}_{\mathrm{i}}^{2}$ & $\mathrm{~h}^{2} \mathrm{r}$ \\
\hline SG & 1.13 & 0.69 & 0.04 & 0.04 & 0.59 & 0.17 \\
\hline ETL & 0.16 & 0.20 & 0.30 & 0.24 & 0.21 & 0.06 \\
\hline LTL & 0.12 & 0.15 & 0.08 & 0.07 & 0.25 & 0.07 \\
\hline ATL & 0.12 & 0.16 & 0.15 & 0.13 & 0.25 & 0.07 \\
\hline RW & 0.24 & 0.27 & 0.08 & 0.07 & 0.30 & 0.08 \\
\hline DBH 13 & 0.88 & 0.62 & 0.60 & 0.40 & 0.84 & 0.26 \\
\hline DBH16 & 0.54 & 0.48 & 0.32 & 0.25 & 0.75 & 0.22 \\
\hline $\mathrm{DBH} 22$ & 0.81 & 0.57 & 0.16 & 0.07 & 0.95 & 0.29 \\
\hline НГІ3 & 0.77 & 0.57 & 0 & 0 & 0.7 & 0.21 \\
\hline
\end{tabular}

Table 8. - Pearson correlation coefficients between parent-tree biological and physical characteristics and progeny family means of wood and growth traits.

\begin{tabular}{|c|c|c|c|c|c|c|c|c|c|c|}
\hline Site & $\begin{array}{l}\text { Parent/Family } \\
\text { characteristics }\end{array}$ & $\mathrm{SG}$ & $\mathrm{ETL}$ & LTL & ATL & $\mathrm{RW}$ & DBH13 & DBHI 6 & DBH22 & HTl3 \\
\hline LK20 & Diameter & 0.09 & 0.20 & 0.15 & 0.19 & 0.04 & -0.13 & -0.05 & -0.03 & -0.25 \\
\hline & Height & 0.08 & -0.16 & -0.32 & -0.33 & 0.11 & -0.27 & 0.16 & -0.15 & -0.30 \\
\hline & Crown height & 0.07 & $-0.37 *$ & $-0.49^{*} *$ & $-0.45^{*}$ & 0.02 & -0.37 & -0.26 & -0.27 & -0.26 \\
\hline & Bark thickness & -0.01 & 0.23 & 0.26 & 0.26 & -0.13 & $0.47^{*}$ & $0.38^{*}$ & 0.34 & $0.42^{*}$ \\
\hline & Elevation & -0.01 & 0.21 & 0.16 & 0.19 & 0.15 & 0.18 & 0.23 & 0.21 & -0.07 \\
\hline & Slope & -0.23 & 0.23 & 0.38 & 0.33 & 0.08 & $0.62^{2+8}$ & $0.54 * *$ & $0.50^{* * *}$ & 0.24 \\
\hline LK24 & Diameter & 0.04 & 0.13 & 0.18 & 0.18 & 0.04 & -0.25 & -0.12 & -0.14 & - \\
\hline & Height & 0.19 & 0.16 & 0.04 & 0.11 & -0.02 & -0.27 & -0.13 & $-0.30 \%$ & - \\
\hline & Crown height & 0.09 & 0.07 & -0.04 & 0.03 & 0.05 & -0.13 & -0.07 & -0.22 & - \\
\hline & Bark thickness & 0.00 & $0.30^{*}$ & 0.18 & 0.26 & 0.06 & 0.11 & $0.30^{*}$ & 0.12 & - \\
\hline & Elcvation & -0.03 & 0.01 & 0.05 & 0.03 & 0.00 & 0.08 & 0.02 & $-(3.06$ & - \\
\hline & Slopc & -0.24 & 0.19 & 0.16 & 0.18 & 0.27 & $0.38 * *$ & $0.36^{*}$ & $0.33^{*}$ & - \\
\hline
\end{tabular}

${ }^{*}$ statistically significant at $\mathrm{p}<=0.05 ;{ }^{*}$ significant at $\mathrm{p}<=0.01$; otherwise not significant. 
between the two sites varied from $0.316(p=0.1743)$ to $0.670(p=0.0012)$. DBH16 had a correlation of 0.670 (the highest), followed by DBH13 (0.552), DBH22 (0.450), and SG (0.506), which indicates the ranking of family means between the two sites were roughly the same and hence were not the major factor for the lack of a sitefamily interaction. This leaves the low family variance (i.e, a narrow range of family means) at site LK24 (Tables 4 and 6 ) as the main reason for the lack of a family-site interaction (Table 5).

The correlation of the physical (elevation and slope) and biological (DBH, height, crown height and bark thickness) traits of the parent trees (Table 1) with the family means of wood and growth traits from the progeny tests are shown in Table 8. Most of the correlation coefficients were low and not statistically significant at both test sites. However, crown height showed a moderate but significant correlation with progeny TL, and bark thickness was correlated with progeny diameter and height at site LK20. These correlations largely disappeared at site LK24 (Table 8). SG, the indicator trait of wood quality, showed essentially no significant correlation with either physical or biological characteristics of the parent trees. The only correlations that showed consistency between the two test sites were between parent-tree slope and the progeny diameters (Table 8). We further employed stepwise regression analysis (SAS procedure GLMSELECT) to screen the joint effect of the parent-tree elevation, slope and their quadratic and interactive terms on progeny performance. The results showed a moderate but significant effect of parent-tree slope, elevation, and slope-elevation interaction on the diameter of their progenies at LK20 (DBH13: $R^{2}=0.38$, $\mathrm{p}<0.001 ; \mathrm{DBH} 16: \mathrm{R}^{2}=0.31, \mathrm{p}<0.005 ; \mathrm{DBH} 22: \mathrm{R}^{2}=0.26$, $\mathrm{p}<0.01)$. The same effects at LK24 were low, though still statistically significant $\left(\mathrm{DBH} 13: \mathrm{R}^{2}=0.15, \mathrm{p}<0.01\right.$; DBH16: $\left.\mathrm{R}^{2}=0.14 ; \mathrm{p}<0.05 ; \mathrm{DBH} 22: \mathrm{R}^{2}=0.12, \mathrm{p}<0.05\right)$. These regression analyses reflect the same results as the correlation analyses (Table 8) and suggest that the steeper the slope and the higher the elevation of the parent tree, the bigger the diameter of the progeny. The results seem to be contrary to the conventional expecta-

Table 9. - Genetic (variance component) and phenotypic (bold) correlation among progeny traits at test site LK20.

\begin{tabular}{|l|c|c|c|c|c|c|}
\hline Traits & SG & ETL & LTL & ATL & RW & DBH16 \\
\hline SG & & 0.06 & 0.27 & 0.19 & -1.21 & -0.83 \\
\hline ETL & $\mathbf{- 0 . 0 7}$ & & 0.63 & 0.91 & 0.12 & 0.30 \\
\hline LTL & $\mathbf{0 . 0 5}$ & $\mathbf{0 . 7 9 * *}$ & & 0.90 & -0.11 & 0.06 \\
\hline ATL & $\mathbf{- 0 . 0 1}$ & $\mathbf{0 . 9 4 * *}$ & $\mathbf{0 . 9 5 * *}$ & & 0.01 & 0.21 \\
\hline RW & $\mathbf{- 0 . 6 7 * *}$ & $\mathbf{- 0 . 1 0}$ & $\mathbf{- 0 . 2 6}$ & $\mathbf{- 0 . 2 0}$ & & 1.01 \\
\hline DBH16 & $\mathbf{- 0 . 5 6 * *}$ & $\mathbf{0 . 2 4}$ & $\mathbf{0 . 1 3}$ & $\mathbf{0 . 2 0}$ & $\mathbf{0 . 6 4 * *}$ & \\
\hline
\end{tabular}

** Statistically significant at $\mathrm{p}<0.01$. tion that such a genetic mode of variation would be in the opposite geographic orientation. On the prospective of in situ conservation of genetic diversity of Taiwania, the topographic component of the species distribution needs to be considered (YANCHUK, 2010).

For phenotypic and genetic correlations between progeny traits, we report only the results from site LK20 (Table 9) because the correlations at site LK24 were abnormal, i.e., most coefficients of genetic correlation were over 1.0 and as high as 4.19. These abnormalities were due to the family variance components approaching 0. For example, the VC estimate for HT13 at LK24 was 0 (Table 4), which rendered the estimate of its genetic correlation with other traits impossible. The correlation of growth traits, which were not measured at the same age as the wood property traits, were not included in Table 9. Their pattern of correlation was similar to that of DBH16.

Genetic correlations showed similar patterns as those of phenotypic correlations in terms of the size and direction of the coefficients (Table 9). Specific gravity showed negative genetic $(-0.83)$ and phenotypic $(-0.56)$ correlation with diameter and RW $(-0.67$ in phenotypic and -1.21 in genetic correlation); it is a common observation with coniferous species that fast growing trees produce low-density wood (ZOBEL and VAN BUIJTENEN, 1989; Wu et al., 2008). The correlation of diameter with RW showed a similar pattern as that of SG but in the opposite direction, reflecting the process of wood formation, i.e. wider ring grows larger diameter, but lower density per unit volume of wood (ZOBEL and VAN BUIJTENEN). The three tracheid measurements were highly correlated within both phenotypic and genetic terms, but showed little correlation with other traits.

\section{Discussion and Conclusion}

Site environment had a large effect on the genetic expression of both wood density and growth of Taiwania in terms of means, variance and heritability estimates. Trees at site LK24 had lower means associated with smaller CVs (narrower range of family means) (Table 6), lower family variance components (Table 4), and lower heritability estimates (Table 7) than those at site LK20 for virtually all traits. Despite such a large site impact, no site-family interaction effect was evident (Table 5); low family variance rather than the ranking of family means at LK24 was the main cause (SHELBOURNE and Campbell, 1976; Matheson and Cotterill, 1990). The result suggests the LK24 site, as a progeny test, adds little additional genetic information to assist either genetic selection or conservation.

The two test sites are within the forest zone where Taiwania is a major plantation species (Lo-CHo et al., 1992; CHIU et al., 2010a, 2010b). Diameter growth at LK20 was comparable to that at other plantations in the same forest zone. For example, at one large growth and yield trial plantation at $1300 \mathrm{~m}$, diameter was about 25 $\mathrm{cm}$ and $30 \mathrm{~cm}$ at age 15 and 20, respectively (CHIU et al., $2010 \mathrm{~b}$ ), which is similar to the DBH16 of $28.1 \mathrm{~cm}$ and DBH22 of $32.9 \mathrm{~cm}$ at LK20 (1200 m). 
The mechanistic understanding of wood formation in relation to environment, particularly climate, has significantly improved in recent decades due to the concern about the potential impact of climate change on wood quality (UKRAINETZ and YANCHUK, 2007; STOEHR et al., 2009; SAMUELSON et al., 2010; KanATAVichai et al., 2010; VIEIRA et al., 2010). These studies either model wood density-climate correlations across the forest landscape using the existing provenance and progeny tests (UKRAINETZ and YANCHUK, 2007; STOEHR et al., 2009) or analyze chronologically the variation of intra-annual ring wood density in relation to seasonal patterns of climate (SAMUELSON et al., 2010; KANATAVICHAI et al., 2010; VIEIRA et al. 2010). These studies reveal that both temperature and precipitation impact wood density and growth interactively depending on their quantity and seasonality, and the species phenology that can efficiently utilize heat and water to produce a high proportion of latewood.

We examined the climatic differences between the two sites (Figure 3). Site LK20 is warmer (Figure 3b, $c$ and $d$ ) and wetter (Figure $3 a$ ) than LK24, and the seasonality of the precipitation is also considerably different between the two sites (Figure 3a). Precipitation at LK24 during the period of April-June and August-October are substantially lower (Figure $3 a$ ), which is also the period when about $80 \%$ of the total growth of Taiwania occurs (KUO, 1995). The test site LK24 is situated on an upper slope close to the ridge of a mountain, which could have amplified the soil moisture deficiency during the species active growth period. This would negatively influence growth and wood density, particularly if it occurred in the period of latewood growth (UKRAINETZ and YANCHUK, 2007; STOEHR et al., 2009; KANATAVICHAI et al., 2010). The ridge site receives much less daily sunlight because of the fog cover during most of the afternoon hours, which can negatively affect growth of the trees at LK24. The joint effect of seasonal pattern of temperature and precipitation and local terrain probably resulted in an unfavourable climate and caused the suppressing effect on growth at site LK24. The necessity of including a progeny test at extreme environment is a debated issue (SKROPPA, 1984; LINDGREN, 1984). The results in this study suggest that a genetic test on a site with a fringe environment adds little value in terms of additional genetic information. The local environment has to be carefully considered in test site selection in mountainous terrain of Taiwan since progeny testing can be a costly undertaking.
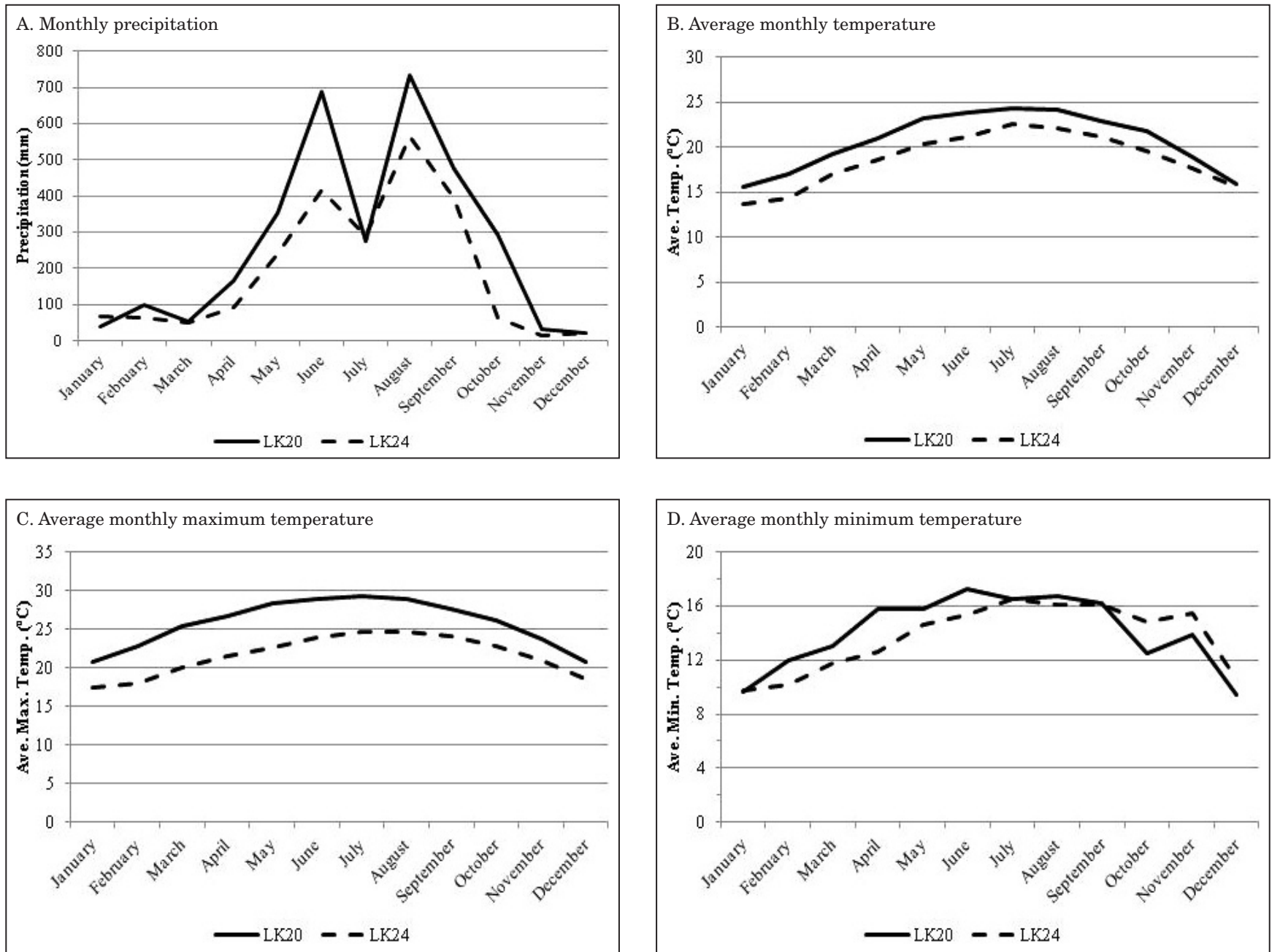

Figure 3. - Comparison of the seasonality of precipitation and temperature between the two test sites. 
Both average SG (0.351) and TL (3.247 $\mathrm{mm})$ at LK20 (Table 6) are slightly lower than 0.397 for the former and $3.488 \mathrm{~mm}$ the latter in the Wood Handbook for Commercial Tree Species in Taiwan (MA et al., 1992). For most species, the data in the Wood Handbook were most likely based on a few older sample trees from natural forests. Taiwan is situated in subtropical climate but the high mountains extend the island climatically to a temperate zone where there exists a rich conifer forest with diverse wood density ranging from 0.354 (Chamaecyparis formosensis) to 0.795 (Taxus chinensis). Preserving this biodiversity in both species and genetic level should be a priority of forest resource management.

Taiwania is botanically interesting, i.e., an ancient species with close phenetic affinity with Sequoiadendron, a monotypic genus, long-lived but with a narrow ecological amplitude in inter-specific competition (LIU and Su, 1983). Taiwania is a giant tree which forms the top of the forest canopy. It is fast growing with high quality wood (KUO, 1995). The species was a target species for harvest in the past and also a species chosen for planting. The species is not in any danger of going extinct but erosion of its genetic variability is a real concern because of the species ecological characteristics, i.e., small seed and infrequent cone crop, late reproductive maturity, and edaphic demands for seedling establishment. A genetic conservation plan is being developed in Taiwan. Before a formal plan of genetic conservation is implemented, the existing family-structured provenance tests should all be properly maintained and protected, at least as a transitional measure (YANCHUK, 2010). Genetic variation of the species is probably very well represented in these tests in view of the large number of parent trees (Table 1) that are well sampled throughout the species range in Taiwan (Figure 1). Longevity confers additional advantage of these tests as a transitional measure of genetic conservation.

\section{Acknowledgements}

The authors recognize the enormous effort by Dr. J. C. YANG, Dr. T. W. Wu and Mr. Y. L. Chung at Taiwan Forestry Research Institute in collecting the seeds, establishing and maintaining the tests. We thank the two referees for their thorough and helpful review. Taiwan National Science Council provided the visiting scientist grant (NSC 100-2811-B-054-001) to C. C. YING.

\section{Literature Cited}

Chiu, C. M., G. Nigh, C. T. Chien and C. C. Ying (2010a): Diameter distribution models for thinned Taiwania (Taiwania cryptomerioides) plantations. Australian Forestry 73: 3-11.

ChiU, C. M., G. Nigh, C. T. Chien and C. C. Ying (2010b): Growth patterns of plantation-grown Taiwania cryptomerioides following thinning. Australian Forestry 73: 246-253.

Chung, J. D., S. R. Guo and J. C. YANG (2001): Preliminary results of flower promotion and seeding in reestablished clonal orchards of Calocedrus formosana (English Summary). Taiwan Journal of Forest Science 16: 131-196.
Chung, J. D., G. Nigh, C. T. Chien and C. C. YING (2011): Genetic variation and tree improvement of Konishii fir (Cunninghamia lanceolata (Lamb.) var. Konishii). Silvae Genetica 60: 196-205.

FARJON, A. and C. N. PAGE (complier) (1999): Status survey and conservation action plan - conifers. International Union of Conservation Network (IUCN). IUCN Publications Services Unit, UK.

FrankLIN, C. L. (1945): Preparing thin sections of synthetic resin and wood-resin composites, a new maceration method for wood. Nature (London) 155: 51.

Gaspar, M. J., J. L. Louzada, M. E. Silva, A. Aguiar and M. H. Almeida (2008): Age trends in genetic parameters of wood density components in 46-sibling families of Pinus Pinaster. Canadian Journal of Forest Research 38: $1470-1477$.

Hsu, K. S., Y. C. Soon and S. Y. LiU (2004): Classification of Forest Vegetation in Taiwan. Taiwan National Museum of Natural Sciences. Taipei, Taiwan.

Kanatavichai, R., D. G. Briggs and E. C. Turnblom (2010): Effect of thinning, fertilization with biosolids, and weather on interannual ring specific gravity and carbon accumulation of a 55-year-old Douglas-fir stand in Western Washington. Canadian Journal of Forest Research 40: 72-85.

Kuo, P. T. (1995): Major Timber Tree Species in Taiwan (in Chinese). Bulletin No. 965, Chinese Forestry Association, Taipei, Taiwan.

LEE, C. H. and H. E. WAHLGREN (1979): Specific gravity sampling with minimal tree damage - a study of red pine. Wood Science 11: 241-245.

LI, Z. C., X. L. WANG and X. J. GE (2008): Genetic diversity of the relict plant Taiwania cryptomerioides Hayata (Cupressaceae) in mainland China. Silvae Genetica 57: 242-249.

LiN, T. P., C. T. WANG and J. C. YANG (1998): Comparison of genetic diversity between Cunninghamia Konishii and C. lanceolata. Journal of Heredity 89: 370-373.

LIN, W. F., L. M. CHANG and T. LIU (1968): Forest vegetation of Taiwan. (Summary in English). Quarterly Journal of Chinese Forestry 1: 1-78.

LINDGREN, D. (1984): Prediction and optimization of genetic gain with regard to genotype $\mathrm{x}$ environment interaction. Studia Forestalia Suecica. No. 166: 15-24.

Littell, R. C., G. A. Milliken, W. W. Stroup and R. D. Wolfinger (1996): SAS System for Mixed Models. SAS Institute Inc., Cary, NC, USA.

LIU, T. (1966): Study on the phytogeography of the conifers and taxads in Taiwan (in Chinese). Bulletin No. 122, Taiwan Forestry Research Institute, Taipei, Taiwan.

LIU, T. S. and H. J. Su (1983): Biosystematic Studies on Taiwania and Numerical Evaluation on the Systems of Taxodiaceae. Special Publication Series No. 2, Taiwan Museum, Taipei, Taiwan.

LiU, Y. C., T. Y. Cheng, C. P. Ho, C. H. OU, C. P. Chu and K. C. LU (1985): Provenance study of Taiwania. Quarterly Journal of Chinese Forestry 18: 1-8.

Lo-Cho, C.N., H. H. Chung and C. M. CHIU (1992): Effects of thinning and pruning on Taiwania (Taiwania cryptomerioides Hayata) plantation in Liukuei area. (English Summary). Bulletin Taiwan Forest Research Institute New Series 7: 291-304.

LU, C. M. (1973): Variation in seedling characters of Taiwania cryptomerioides from various provenances (I). Research Report 246, Taiwan Forestry Research Institute, Taipei, Taiwan. 
LU, C. M. (1975): Variation in seedling characters of Taiwania cryptomerioides from various provenances (II). Research Report 261, Taiwan Forestry Research Institute, Taipei, Taiwan.

MA, T. P., C. C. Chen, J. C. Hsiung, C. Y. Hwang, S. S. CHEN and S.Y. JAI (1992): Wood Handbook of Major Commercial Tree Species in Taiwan (in Chinese). General Report No. 1, Taiwan Forestry Research Institute, Taipei, Taiwan.

NYQUIST, W. E. (1991): Estimation of heritability and prediction of selection response in plant populations. Critical Review in Plant Sciences 10: 235-322.

Matheson, A. G. and P. P. CotTerill (1990): Utility of genotype $\mathrm{x}$ environment interactions. Forest Ecology and Management 30: 159-174.

SAmuelson, L. J., T. L. Eberhardt, J. R. Butnor, T. A. STOKES and K. H. Johnson (2010): Maximum growth in loblolly pine: results from a 47-year-old spacing study in Hawaii. Canadian Journal of Forest Research 40 1914-1929.

SAS Institute Inc. (2004): SAS OnlineDoc ${ }^{\circledR}$ 9.1.3. Cary, NC.

Shelbourne, C. J. A. and R. K. CAmpbell (1976): The impact of genotype environment interactions on tree improvement strategies. pp. 73-93. In: Proceedings IUFRO Joint Meeting Working Parties on Populations and Ecological Genetics. Bordeaux, France.

SkRopPA, T. (1984): A critical evaluation of methods available to estimate the genotype $\mathrm{x}$ environment interaction. Studia Forestalia Suecica. No. 166: 3-14.

SMith, D. M. (1954): Maximum moisture content method for determining specific gravity of small wood specimens. Report No. 2014, Forest Product Laboratory. USDA Forest Service. Madison, Wisconsin, USA.

SNedecor, G. W. and W. G. Cochran (1980): Statistical Methods. The Iowa State University Press. Ames, Iowa, USA.

Stoehr, M. U., N. K. Ukrainetz, L. K. HaYton and A. D. YANCHUK (2009): Current and future trends in juvenile wood density for coastal Douglas-fir. Canadian Journal of Forest Research 39: 1415-1419.

UkRAINETZ, N. K. and A. D. YANCHUK (2007): Environmental effects on relative wood density in lodgepole pine and strategies for improved growth and density breeds. pp. 169-170. In: Proceedings of the $29^{\text {th }}$ Southern Forest Tree Improvement Conf., Tree Improvement in North America: past, present and future. WFGA/SFTIC
Joint Meeting, Edited by T. D. BYran and M. L. Rust, Galveston, Texas, 19-22 June 2007.

VIEIRA, J., F. CAMPELO and C. NABAIS (2010): Intra-annual density fluctuations of Pinus pinaster are a record of climate changes in the western Mediterranean region. Canadian Journal of Forest Research 40: 1567-1575.

WORLD FOREST INSTITUTE (2001): Taiwan's forest sector. AWFI Market Brief Series, Portland. OR. Accessed at: http://wfi.worldforestry.org/media/publications/marketbriefs/Taiwan_brief.pdf.

Wu, H. X., M. Ivkovic, W. J. Gapare, A. C. Matheson, B. S. Baltunis, M. B. Powell and T. A. McRae (2008): Breeding for wood quality and profit in Pinus radiata: a review of genetic parameter estimates and implications for breeding and development. New Zealand Journal of Forestry Science 38: 56-87.

Wunder, J., B. Reineking, F.-W. Hillgarter, C. Bigler and H. BugmanN (2011): Long-term effects of increment coring on Norway spruce mortality. Canadian Journal of Forest Research 41: 2326-2336.

YANG, J. C., C. H. LeE and C. M. ChIU (1998): Precision of estimating Luanta fir specific gravity by a few outer growth rings. Taiwan Journal of Forest Science 13 251-257.

YANG, J. C., C. H. LeE and C. M. CHIU (2001a): Genetic variation of wood density in Luanta fir tested in central Taiwan. Wood and Fiber Science 33: 486-491.

YANG, J. C., C. M. ChIU, T. P. LIN and F. H. KUNG (2001b): No clinal variation in Cunninghamia lanceolata wood density sampled from thirteen Chinese Provinces. Taiwan Journal of Forest Science 19: 65-80.

YANG, J. C. and C. M. CHIU (2006): Genetic variation of wood specific gravity and tracheid length of open-pollinated progeny families in Calocedrus formosana. Taiwan Journal of Forest Science 21: 305-315.

YANCHUK, A. D. and G. K. KISS (1993): Genetic variation in growth and wood specific gravity and its utility in the improvement of interior spruce in British Columbia. Silvae Genetica 42: 141-148.

YANCHUK, A. D. (2010): The role and future challenges of Ex Situ gene conservation approaches for forest tree genetic resources. pp. 11-20. In: Tree Seed Symposium: recent advances in seed research and ex situ conservation. Taipei, Taiwan. August 16-18, 2010.

Zobel, B. J. and J. P. VAN BuiJtenen (1989): Wood Variation: Its Causes and Control. Springer-Verlag, Berlin. 